\title{
Kinetics of sodium borohydride hydrolysis reaction for hydrogen generation
}

\author{
Ai-Jen Hung ${ }^{a}$, Shing-Fen Tsai ${ }^{b}$, Ya-Yi Hsu ${ }^{b}$, Jie-Ren $\mathrm{Ku}^{b}$, Yih-Hang Chen ${ }^{c}$, \\ Cheng-Ching $\mathrm{Yu}^{a, *}$ \\ ${ }^{a}$ Department of Chemical Engineering, National Taiwan University, Taipei 106-17, Taiwan \\ ${ }^{b}$ Energy and Environment Research Laboratories (EEL), Industrial Technology Research Institute (ITRI), Hsinchu 310, Taiwan \\ ${ }^{\mathrm{c}}$ Department of Process Engineering, CTCI Corporation, Taipei 106, Taiwan
}

\section{A R T I C L E I N F O}

Article history:

Received 13 March 2008

Received in revised form

29 July 2008

Accepted 29 July 2008

Available online 11 September 2008

Keywords:

Kinetics

Sodium borohydride

Hydrolysis reaction

Hydrogen generation

\begin{abstract}
A B S T R A C T
In this work, a ruthenium catalyst was prepared for hydrogen generation from the hydrolysis reaction of an alkaline sodium borohydride solution. The reactions were carried out in a batch reactor at temperatures of $10,30,40$ and $60^{\circ} \mathrm{C}$ for at least $70 \%$ conversion or 500 min, whichever came first. The experimental data was fitted to the following three kinetic models: zero-order, first-order, and Langmuir-Hinshelwood. The results indicate that the Langmuir-Hinshelwood model gives a reasonable description of the hydrogen generation rate over the entire temperature range studied as well as the time spans of the experiments. The zero-order model gives good behavior description only at relatively low temperature, i.e. $10^{\circ} \mathrm{C}$. The first-order model works fairly well for a temperature range up to $30^{\circ} \mathrm{C}$.
\end{abstract}

( 2008 International Association for Hydrogen Energy. Published by Elsevier Ltd. All rights

\section{Introduction}

Hydrogen has become one of the most promising future energy resources due to concerns about global warming and the depletion of fossil fuels. Hydrogen generation from the hydrolysis reaction of an alkaline sodium borohydride solution $\left(\mathrm{NaBH}_{4}\right)$ has drawn much attention due to its theoretically high hydrogen storage capacity (10.8 wt\%). In addition, it is favored as the hydrogen supplier for proton exchange membrane (PEM) fuel cells due to the high purity of the hydrogen.

A hydrolysis reaction takes place only when an alkaline $\mathrm{NaBH}_{4}$ solution is in contact with certain catalysts. Different catalysts such as ruthenium (Ru) [1-7], platinum (Pt) $[8,9]$, palladium (Pd) [10], nickel (Ni) [11,12], cobalt (Co) $[11,13,14]$, Co-B [15,16], Ni-B [17], Ni-Co-B [18], carbon nanotubes (CNT) [19] have been extensively studied.
For the design of reactors, it is essential to determine a reliable kinetic model for the hydrogen generation. Hydrogen generation from an alkaline $\mathrm{NaBH}_{4}$ solution has been extensively investigated and three kinetic models have been proposed [1-7,10-13,15-19]. They are zero-order, firstorder and Langmuir-Hinshelwood.

Several authors have used a zero-order model. Amendola et al. [1] used Ru on IRA-400 as the catalyst to study the effect of different temperatures on the kinetics of the hydrolysis reaction. Factors including the concentration of $\mathrm{NaBH}_{4}$, the concentration of sodium hydroxide $(\mathrm{NaOH})$ and the reaction temperature (which could affect the hydrogen generation rates) were investigated using the catalyst $\mathrm{Ru}$ on different supports in $[2,3]$. The catalysts Co [11,13], Ni [11], Co-B $[15,16]$, Ni-B [17] and Ni-Co-B [18] were implemented for the hydrolysis reaction.

\footnotetext{
* Corresponding author. Fax: +88622362 3040.

E-mail address: ccyu@ntu.edu.tw (C.-C. Yu).
} 0360-3199/\$ - see front matter @ 2008 International Association for Hydrogen Energy. Published by Elsevier Ltd. All rights reserved. doi:10.1016/j.ijhydene.2008.07.109 


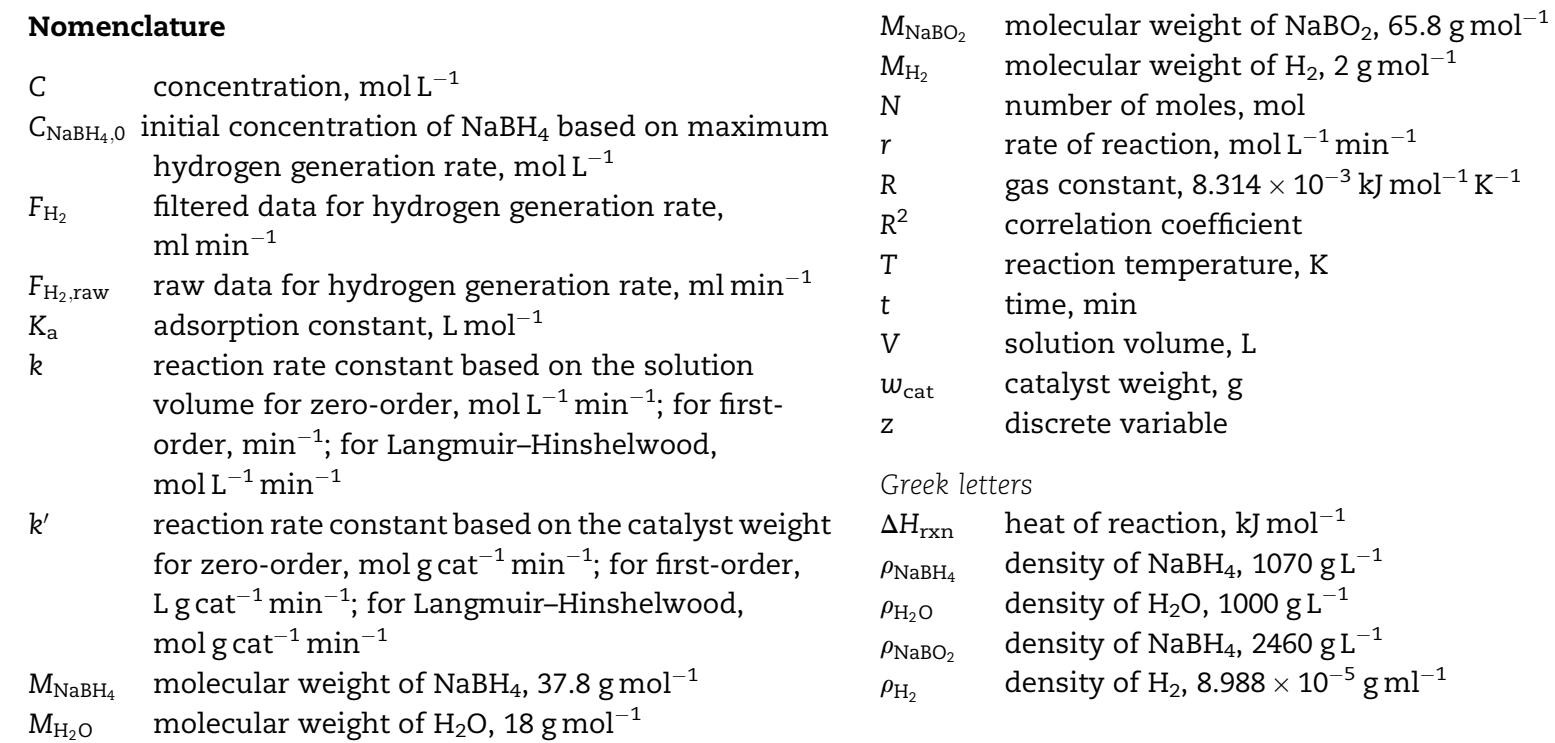

Other authors have used a first-order model. Ozkar and Zahmakiran $[4,5]$ used a water-dispersible $\mathrm{Ru}(0)$ nanocluster catalyst to increase activity. Shang and Chen [6] explored the effect of a concentrated $\mathrm{NaBH}_{4}$ solution on hydrogen generation rates. The performance and reliability of carbon nanotubes (CNT) as the catalyst for the hydrolysis reaction were investigated in Ref. [19]. The synthesis and characterization of a water-dispersible $\mathrm{Ni}(0)$ nanocluster catalyst was explored in
Ref. [12] and the activity of Pd on the hydrolysis reaction was investigated in Ref. [10].

Finally, at least one author has used a Langmuir-Hinshelwood model. Zhang et al. [7] used the commercial catalyst $\mathrm{Ru}$ to analyze the effects of different substrates, the catalyst sizes, the stirring speed and the reaction temperature on the hydrogen generation rate. Table 1 summarizes published investigations of the kinetics of the

Table 1 - Kinetic models for different catalysts, initial concentration of $\mathrm{NaBH}_{4(\mathrm{aq})}$, temperature ranges, activation energy and time spans

\begin{tabular}{|c|c|c|c|c|c|c|}
\hline Catalyst/support & $\begin{array}{l}\text { Initial concentration } \\
\text { of } \mathrm{NaBH}_{4(\mathrm{aq})}\end{array}$ & $\begin{array}{l}\text { Kinetic } \\
\text { model }\end{array}$ & $\begin{array}{l}\text { Temp. } \\
\text { range }\left({ }^{\circ} \mathrm{C}\right)\end{array}$ & $\begin{array}{c}\text { Activation } \\
\text { energy } \\
(\mathrm{kJ} / \mathrm{mol})\end{array}$ & $\begin{array}{l}\text { Time } \\
\text { span } \\
\text { (min) }\end{array}$ & Reference \\
\hline $\mathrm{Ru}(5 \mathrm{wt} \%) / \mathrm{IRA}-400$ & 20 wt $\% \mathrm{NaBH}_{4}+10$ wt $\% \mathrm{NaOH}$ & Zero-order & $25-55$ & 47.0 & 27 & Amendola et al. [1] \\
\hline $\mathrm{Ru}(5 \mathrm{wt} \%) / \mathrm{IRA}-400$ & 7.5 wt $\% \mathrm{NaBH}_{4}+1 \mathrm{wt} \% \mathrm{NaOH}$ & Zero-order & $0-40$ & 56.0 & 42 & Amendola et al. [2] \\
\hline $\mathrm{Ru}(1 \mathrm{wt} \%) / \mathrm{IR}-120$ & 5 wt $\% \mathrm{NaBH}_{4}+1 \mathrm{wt} \% \mathrm{NaOH}$ & Zero-order & $5-55$ & 49.7 & 60 & Hsueh et al. [3] \\
\hline $\mathrm{Ni}$ & 0.9 wt $\% \mathrm{NaBH}_{4}+10$ wt\% $\mathrm{NaOH}$ & Zero-order & $10-50$ & 62.7 & 150 & Liu et al. [11] \\
\hline Co & & Zero-order & $10-50$ & 41.9 & 30 & \\
\hline Raney Ni & & Zero-order & $10-30$ & 50.7 & 50 & \\
\hline Raney Co & & Zero-order & $10-30$ & 53.7 & 50 & \\
\hline Raney $\mathrm{Ni}_{50} \mathrm{Co}_{50}$ & & Zero-order & $10-30$ & 52.5 & 30 & \\
\hline Co-B & 20 wt $\% \mathrm{NaBH}_{4}+5$ wt $\% \mathrm{NaOH}$ & Zero-order & $10-30$ & 64.9 & 40 & Jeong et al. [15] \\
\hline Co-B & $0.7 w t \% \mathrm{NaBH}_{4}+4 \mathrm{wt} \% \mathrm{NaOH}$ & Zero-order & $25-40$ & 57.8 & 14 & Zhao et al. [16] \\
\hline $\mathrm{Co} / \gamma-\mathrm{Al}_{2} \mathrm{O}_{3}$ & 5 wt $\% \mathrm{NaBH}_{4}+5 \mathrm{wt} \% \mathrm{NaOH}$ & Zero-order & $30-50$ & 32.6 & 80 & Ye et al. [13] \\
\hline $\mathrm{Ni}_{x} \mathrm{~B}$ & $1.5 \mathrm{wt} \% \mathrm{NaBH}_{4}+10 \mathrm{wt} \% \mathrm{NaOH}$ & Zero-order & $20-60$ & 56.0 & 35 & Dong et al. [17] \\
\hline $\mathrm{Ni}-\mathrm{Co}-\mathrm{B}$ & $4.7 \mathrm{wt} \% \mathrm{NaBH}_{4}+15 \mathrm{wt} \% \mathrm{NaOH}$ & Zero-order & $8-27$ & 62.0 & 50 & Ingersoll et al. [18] \\
\hline $\mathrm{Ru}(0)$ nanoclusters & 0.5 wt $\% \mathrm{NaBH}_{4}$ & First-order & $30-45$ & 28.5 & 5 & Ozkar and Zahmakiran [4] \\
\hline $\mathrm{Ru}(0)$ nanoclusters & 0.5 wt $\% \mathrm{NaBH}_{4}+10$ wt\% $\mathrm{NaOH}$ & First-order & $25-55$ & 41.0 & 6 & Zahmakiran and Ozkar [5] \\
\hline $\mathrm{Ru} / \mathrm{C}$ & 5 wt $\% \mathrm{NaBH}_{4}+5$ wt $\% \mathrm{NaOH}$ & First-order & $42-60$ & 37.3 & 35 & Shang and Chen [6] \\
\hline Carbon nanotubes (CNT) & $1 \mathrm{wt} \% \mathrm{NaBH}_{4}$ & First-order & $29-59$ & 19.0 & 120 & Pena-Alonso et al. [19] \\
\hline $\mathrm{Ni}(0)$ nanoclusters & 0.5 wt\% $\mathrm{NaBH}_{4}$ & First-order & $25-45$ & 54.0 & 100 & Metin and Ozkar [12] \\
\hline $\mathrm{Pd} / \mathrm{C}$ & 0.5 wt $\% \mathrm{NaBH}_{4}$ & First-order & $10-55$ & 28.0 & 20 & Patel et al. [10] \\
\hline $\mathrm{Ru} / \mathrm{C}$ & 0.8 wt $\% \mathrm{NaBH}_{4}+3 \mathrm{wt} \% \mathrm{NaOH}$ & $\begin{array}{l}\text { Langmuir- } \\
\text { Hinshelwood }\end{array}$ & $25-85$ & 67.0 & 14 & Zhang et al. [7] \\
\hline $\mathrm{Ru} / \gamma-\mathrm{Al}_{2} \mathrm{O}_{3}$ & $12 \mathrm{wt} \% \mathrm{NaBH}_{4}+1 \mathrm{wt} \% \mathrm{NaOH}$ & Zero-order & $10-60$ & 54.9 & 500 & This work \\
\hline $\mathrm{Ru} / \gamma-\mathrm{Al}_{2} \mathrm{O}_{3}$ & $12 \mathrm{wt} \% \mathrm{NaBH}_{4}+1 \mathrm{wt} \% \mathrm{NaOH}$ & First-order & $10-60$ & 55.7 & 500 & This work \\
\hline $\mathrm{Ru} / \gamma-\mathrm{Al}_{2} \mathrm{O}_{3}$ & 12 wt\% $\mathrm{NaBH}_{4}+1$ wt\% $\mathrm{NaOH}$ & $\begin{array}{l}\text { Langmuir- } \\
\text { Hinshelwood }\end{array}$ & $10-60$ & 55.4 & 500 & This work \\
\hline
\end{tabular}




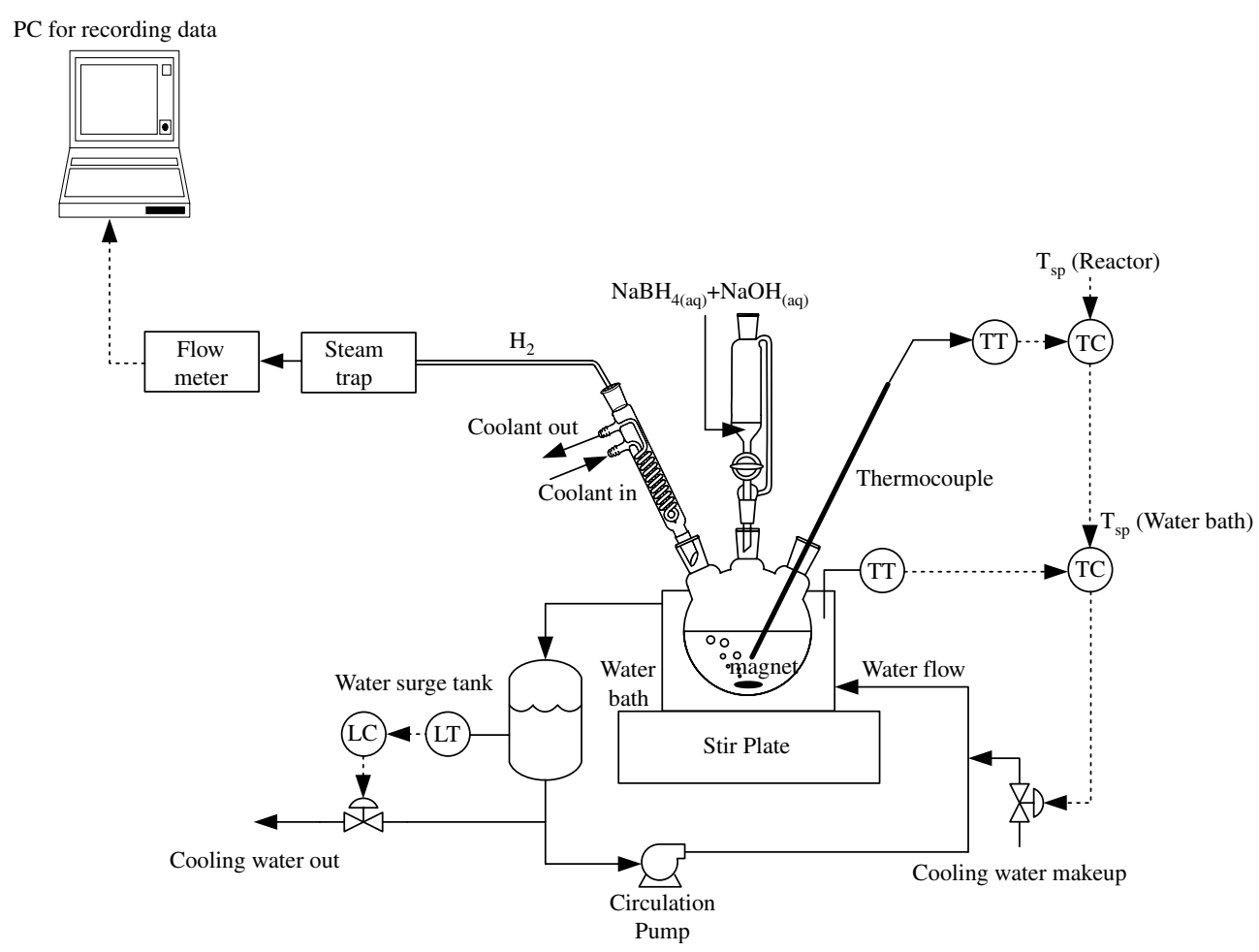

Fig. 1 - Experimental setup for hydrogen generation from the hydrolysis reaction of an alkaline $\mathrm{NaBH}_{4} \mathrm{solution}$

hydrolysis of $\mathrm{NaBH}_{4}$, including the kinetic models for different catalysts, initial concentration of the alkaline $\mathrm{NaBH}_{4}$ solution, temperature ranges, activation energy and time spans. As shown in Table 1, the models are mostly zero-order or first-order with the exception of the work of Ref. [7]. Furthermore, the time spans of the experiments range from 5 to $150 \mathrm{~min}$. Because we are interested in

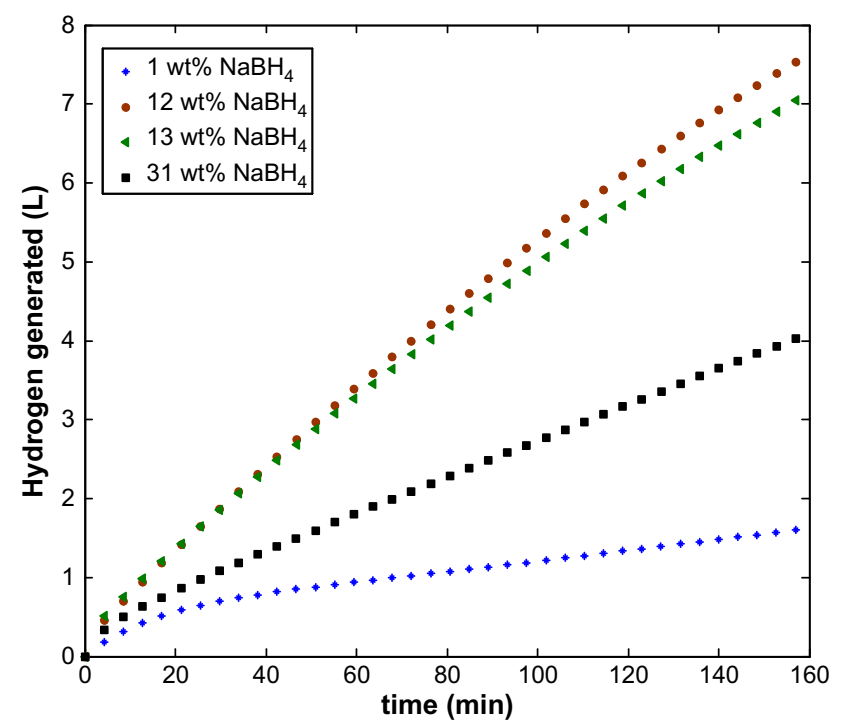

Fig. 2 - Hydrogen generation volume with respect to time at the concentration of $\mathrm{NaBH}_{4}$ of 1, 12, 13 and $31 \mathrm{wt} \%$ at $30{ }^{\circ} \mathrm{C}$ with the concentration of $\mathrm{NaOH}$ at a constant $1 \mathrm{wt} \%$. utilizing the kinetic model to design a hydrogen generation device, a model capable of describing the hydrogen generation rate over the entire batch reactor operation is preferred. The objective of this work is to determine an appropriate kinetic model of this hydrolysis reaction in a batch reactor based on experiments at four different temperatures.

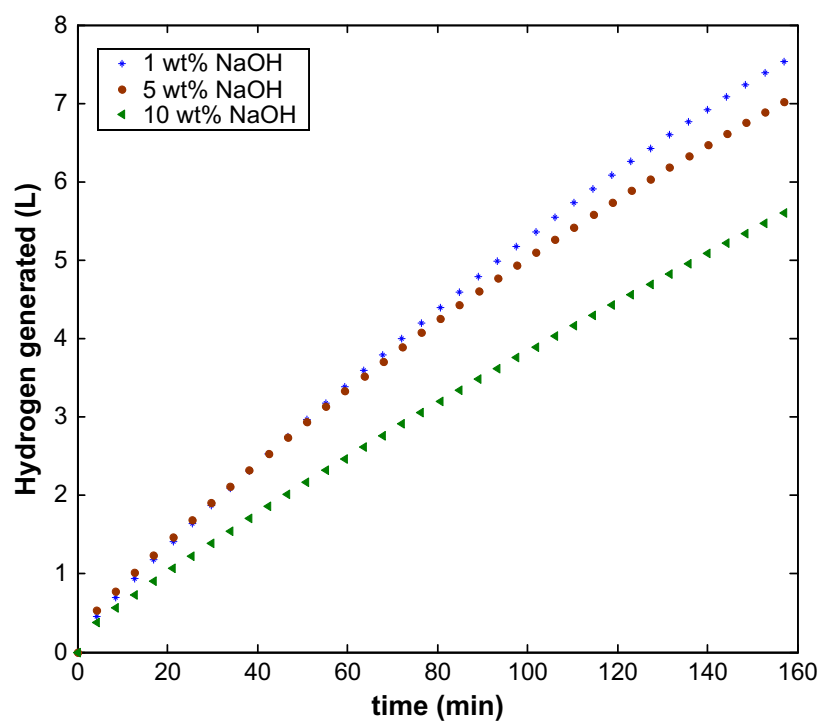

Fig. 3 - Hydrogen generation volume with respect to time at the concentration of $\mathrm{NaOH}$ of 1,5 and $10 \mathrm{wt} \%$ at $30^{\circ} \mathrm{C}$ with the concentration of $\mathrm{NaBH}_{4}$ at a constant $12 \mathrm{wt} \%$. 


\section{Experimental}

\subsection{Hydrolysis reaction}

A $\mathrm{NaBH}_{4}$ solution with an alkaline stabilizer, $\mathrm{NaOH}$, reacts with water to generate hydrogen and sodium metaborate $\left(\mathrm{NaBO}_{2}\right)$ in the presence of a catalyst. The catalytic hydrolysis reaction for hydrogen generation is irreversible, heterogeneous, and highly exothermic, with the heat of reaction of $210 \mathrm{~kJ} / \mathrm{mol}[20]$ :

$$
\begin{aligned}
& \mathrm{NaBH}_{4(\mathrm{aq})}+2 \mathrm{H}_{2} \mathrm{O}_{(\mathrm{l})} \stackrel{\text { catalyst }}{\longrightarrow} 4 \mathrm{H}_{2(\mathrm{~g})}+\mathrm{NaBO}_{2(\mathrm{aq})} \quad \Delta \mathrm{H}_{\mathrm{rxn}} \\
& \quad=-210 \mathrm{~kJ} / \mathrm{mol}
\end{aligned}
$$

This reaction system also has several advantages, including, hydrogen can be produced even when the temperature is $0{ }^{\circ} \mathrm{C}$, the hydrogen generation rate can be easily controlled, and an alkaline $\mathrm{NaBH}_{4}$ solution is nonflammable and stable.

\subsection{Preparation of $\mathrm{Ru} / \gamma-\mathrm{Al}_{2} \mathrm{O}_{3}$ catalyst}

The metal Ru was selected as a catalyst for hydrogen generation due to high hydrogen production [21,22] and gamma-alumina $\left(\gamma-\mathrm{Al}_{2} \mathrm{O}_{3}\right)$ was used as the support. The catalyst $\mathrm{Ru} / \gamma-\mathrm{Al}_{2} \mathrm{O}_{3}$ was prepared by the impregnation-reduction method. The synthesis procedure is summarized as follows:

1. Ten grams of $\gamma-\mathrm{Al}_{2} \mathrm{O}_{3}$ pellets (Alfa Aesar) were dehydrated at $600{ }^{\circ} \mathrm{C}$.

2. The $\gamma-\mathrm{Al}_{2} \mathrm{O}_{3}$ pellets were placed in $10 \mathrm{ml}$ of $0.24 \mathrm{M}$ $\mathrm{RuCl}_{3} \cdot 3 \mathrm{H}_{2} \mathrm{O}$ (Sigma-Aldrich) for $24 \mathrm{~h}$.

3. They were then dried for $2 \mathrm{~h}$ at $120^{\circ} \mathrm{C}$ in nitrogen and then calcined for $3 \mathrm{~h}$ at $550^{\circ} \mathrm{C}$ in nitrogen.

4. Finally, they were reduced for $6 \mathrm{~h}$ at $700{ }^{\circ} \mathrm{C}$ in hydrogen, producing the catalyst $\mathrm{Ru} / \gamma-\mathrm{Al}_{2} \mathrm{O}_{3}$.

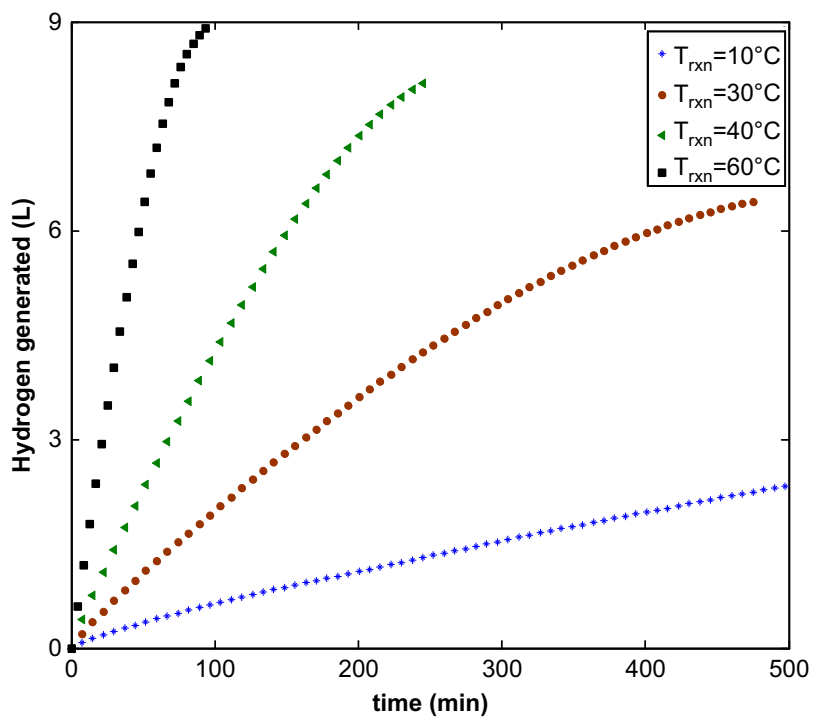

Fig. 4 - Hydrogen generation volume with respect to time at temperatures of $10,30,40$, and $60^{\circ} \mathrm{C}$ with the concentrations of $\mathrm{NaBH}_{4}$ and $\mathrm{NaOH}$ at 12 and $1 \mathrm{wt} \%$, respectively.

\subsection{Experimental setup}

The experiments for the hydrolysis reaction were performed at the Industrial Technology Research Institute/Energy and Environment Research Laboratories (ITRI/EEL) facility in Hsinchu. Fig. 1 shows the experimental setup for hydrogen generation from the hydrolysis reaction of an alkaline $\mathrm{NaBH}_{4}$ solution. The reaction took place in a round-bottomed glassware flask with three necks. A thermocouple in the first neck was used to monitor the solution temperature which was kept constant, via a thermostatic circulation water bath, to within $\pm 0.1^{\circ} \mathrm{C}$ of the temperature set point. The second neck was connected to a funnel, which contained an alkaline $\mathrm{NaBH}_{4}$ solution. The reaction was initiated when $30 \mathrm{ml}$ of $12 \mathrm{wt} \%$ $\mathrm{NaBH}_{4}$ solution, including $1 \mathrm{wt} \% \mathrm{NaOH}$ solution as an alkaline stabilizer, was added to the flask to come into contact with $0.5 \mathrm{~g}$ of the catalyst $\mathrm{Ru} / \gamma-\mathrm{Al}_{2} \mathrm{O}_{3}$. The catalyst was pre-soaked in $16 \mathrm{ml}$ of de-ionized water. This level of solution concentration was used because it was found to produce the highest level of hydrogen generation, as shown in Figs. 2 and 3. As can be seen in Fig. 2, the hydrogen generation decreases with an increase in $\mathrm{NaBH}_{4}$ concentration from 12 to $31 \mathrm{wt} \%$. Similarly, as can be

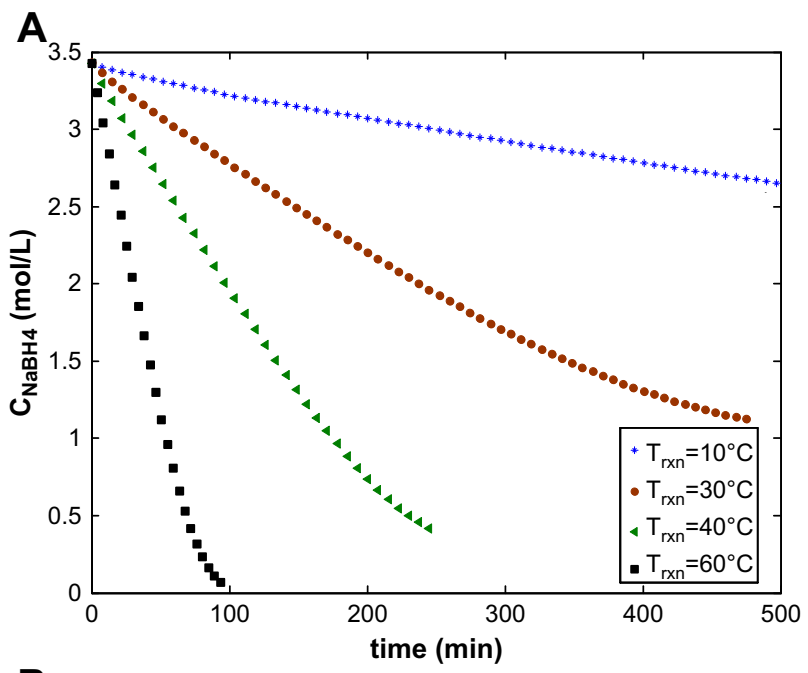

B

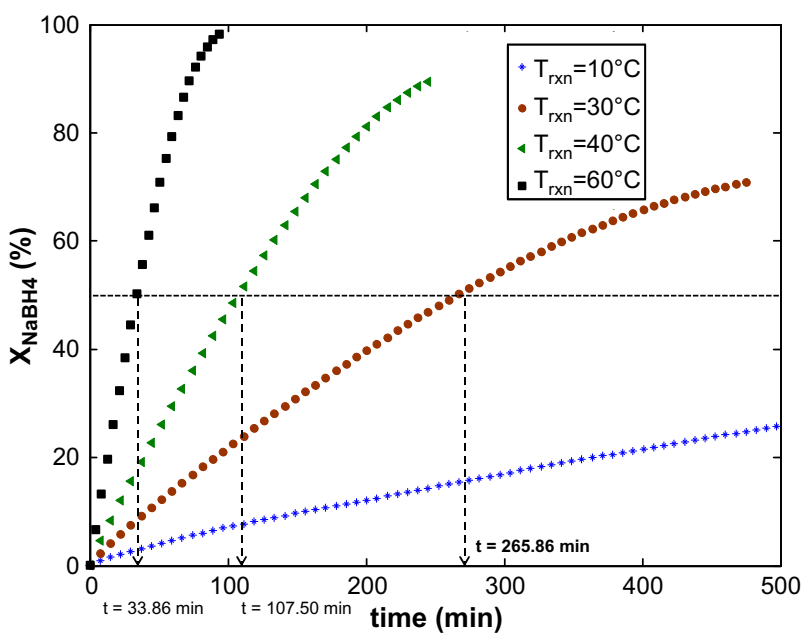

Fig. 5 - (A) Concentration of $\mathrm{NaBH}_{4}$ with respect to time, (B) conversion of $\mathrm{NaBH}_{4}$ with respect to time for four temperatures: $10^{\circ} \mathrm{C}, 30^{\circ} \mathrm{C}, 40^{\circ} \mathrm{C}$, and $60^{\circ} \mathrm{C}$. 

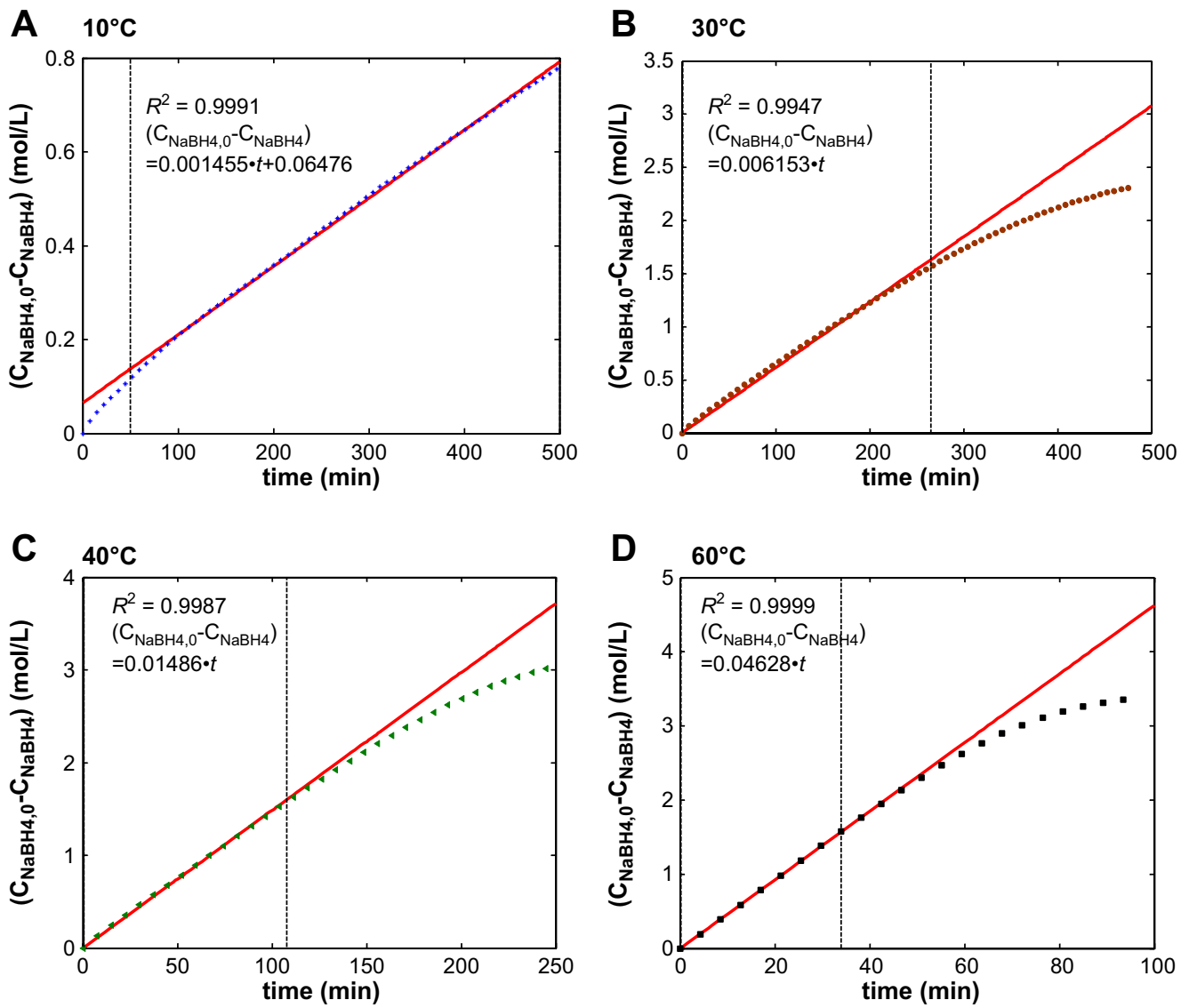

Fig. 6 - Linear regression based on zero-order while the temperature is (A) $10^{\circ} \mathrm{C}$ (B) $30^{\circ} \mathrm{C}(\mathrm{C}) 40^{\circ} \mathrm{C}$ (D) $60^{\circ} \mathrm{C}$.

seen in Fig. 3, the hydrogen generation decreases when the $\mathrm{NaOH}$ concentration is increased. The reagent solution was stirred by a magnet to maintain a uniform temperature. The hydrogen that was generated exited through the third neck into a coil condenser and then passed through a steam trap in order to remove the water vapor. During the experiments, the hydrogen generation rates were measured by a flow meter at the following temperatures: $10,30,40$, and $60^{\circ} \mathrm{C}$. The sampling times for the temperature and flow measurements are $1.06 \mathrm{~s}$.

\section{Results and discussions}

\subsection{Kinetics}

\subsubsection{Data treatment}

Because of the noise associated with measurements, it is desirable to use an exponential filter to smooth the raw data for hydrogen generation rates. Raw data was smoothed with a filter with a time constant of $0.42 \mathrm{~min}$. The relatively small time constant will not alter the dynamic behavior of the reaction because the process time constant is much large, at least $40 \mathrm{~min}$. The Appendix shows the hydrogen generation rate before and after the filtering at 30 and $60^{\circ} \mathrm{C}$. The accumulative volumetric hydrogen generation with respect to time is shown in Fig. 4 at temperatures of 10, 30, 40, and $60^{\circ} \mathrm{C}$.
For kinetic analysis, it is preferable to convert the hydrogen generation rate into the reactant (sodium borohydride) concentration - both as functions of time. From the reaction stoichiometry, the number of moles of $\mathrm{NaBH}_{4}$ remaining in the batch reactor with respect to time can be expressed as:

$\mathrm{N}_{\mathrm{NaBH}_{4}}(z)=\mathrm{N}_{\mathrm{NaBH}_{4}}(\mathrm{z}-1)-\mathrm{N}_{\mathrm{H}_{2}}(\mathrm{z}-1) / 4$

where $\mathrm{N}$ is the number of moles and $\mathrm{z}$ is the discrete variable. The number of moles of $\mathrm{H}_{2} \mathrm{O}$ remaining in the batch reactor with respect to time is:

$N_{\mathrm{H}_{2} \mathrm{O}}(z)=N_{\mathrm{H}_{2} \mathrm{O}}(z-1)-N_{\mathrm{H}_{2}}(z-1) / 2$

The number of moles of $\mathrm{NaBO}_{2}$ remaining in the batch reactor with respect to time is:

$\mathrm{N}_{\mathrm{NaBO}_{2}}(z)=\mathrm{N}_{\mathrm{NaBO}_{2}}(z-1)+\mathrm{N}_{\mathrm{H}_{2}}(z-1) / 4$

The solution volume with respect to time can then be evaluated as follows:

$V(z)=\left(\frac{N_{\mathrm{NaBH}_{4}}(z) \cdot \mathrm{M}_{\mathrm{NaBH}_{4}}}{\rho_{\mathrm{NaBH}_{4}}}+\frac{N_{\mathrm{H}_{2} \mathrm{O}}(z) \cdot \mathrm{M}_{\mathrm{H}_{2} \mathrm{O}}}{\rho_{\mathrm{H}_{2} \mathrm{O}}}+\frac{N_{\mathrm{NaBO}_{2}}(z) \cdot \mathrm{M}_{\mathrm{NaBO}_{2}}}{\rho_{\mathrm{NaBO}_{2}}}\right)$

where $\mathrm{V}$ is the solution volume, $\rho$ denotes the density, $\mathrm{M}$ stands for the molecular weight. Consequently, the concentration of $\mathrm{NaBH}_{4}$ as a function of time can be obtained from $\mathrm{C}_{\mathrm{NaBH} 4}=\mathrm{N}_{\mathrm{NaBH} 4} / \mathrm{V}$ as shown in Fig. 5(A). The corresponding conversion of $\mathrm{NaBH}_{4}$ can be calculated as shown in Fig. 5(B). In 
Table 2 - Products of reaction rate constant and catalyst weight, correlation coefficients of regression and correlation coefficients for the entire range for zero-order, first-order, Langmuir-Hinshelwood at 10, 30, 40, and $60^{\circ} \mathrm{C}$

$$
\begin{gathered}
\text { Temp. }\left({ }^{\circ} \mathrm{C}\right) \quad \text { for regression }(\mathrm{min}) \\
\end{gathered}
$$

$k(\mathrm{~mol} / \mathrm{L} / \mathrm{min})$
Correlation

coefficient $\left(R^{2}\right)$

of regression
Correlation

coefficient $\left(R^{2}\right)$

\begin{tabular}{|c|c|c|c|c|c|}
\hline \multirow[t]{5}{*}{ Zero-order } & 10 & $50-500$ & 0.001455 & 0.9991 & 0.9957 \\
\hline & 30 & $0-265.86$ & 0.006153 & 0.9947 & 0.8965 \\
\hline & 40 & $0-107.50$ & 0.01486 & 0.9987 & 0.9424 \\
\hline & 60 & $0-33.86$ & 0.04628 & 0.9999 & 0.8969 \\
\hline & Temp. $\left({ }^{\circ} \mathrm{C}\right)$ & $\begin{array}{l}\text { Time span } \\
\text { for regression (min) }\end{array}$ & $k(1 / \min )$ & $\begin{array}{l}\text { Correlation } \\
\text { coefficient }\left(R^{2}\right) \\
\text { of regression }\end{array}$ & $\begin{array}{l}\text { Correlation } \\
\text { coefficient }\left(R^{2}\right) \\
\text { for the entire } \\
\text { range }^{a}\end{array}$ \\
\hline \multirow[t]{5}{*}{ First-order } & 10 & $50-500$ & 0.0004909 & 0.9999 & 0.9989 \\
\hline & 30 & $0-500$ & 0.002356 & 0.9967 & 0.9967 \\
\hline & 40 & $0-107.50$ & 0.005347 & 0.9929 & 0.6446 \\
\hline & 60 & $0-33.86$ & 0.01663 & 0.9859 & 0.2663 \\
\hline & Temp. $\left({ }^{\circ} \mathrm{C}\right)$ & $\begin{array}{l}\text { Time span } \\
\text { for regression ( } \mathrm{min})\end{array}$ & $k(\mathrm{~mol} / \mathrm{L} / \mathrm{min})$ & $\begin{array}{l}\text { Correlation } \\
\text { coefficient }\left(R^{2}\right) \\
\text { of regression }\end{array}$ & $\begin{array}{l}\text { Correlation } \\
\text { coefficient }\left(R^{2}\right) \\
\text { for the entire } \\
\text { range }^{a}\end{array}$ \\
\hline \multirow[t]{4}{*}{ Langmuir-Hinshelwood } & 10 & $50-500$ & 0.001705 & 0.9993 & 0.9963 \\
\hline & 30 & $0-265.86$ & 0.007287 & 0.9971 & 0.9835 \\
\hline & 40 & $0-250$ & 0.01729 & 0.9990 & 0.9990 \\
\hline & 60 & $0-100$ & 0.05659 & 0.9997 & 0.9997 \\
\hline
\end{tabular}

for the entire range $^{a}$

a Full time span range: $0-500 \mathrm{~min}$ for 10 and $30^{\circ} \mathrm{C}, 0-250 \mathrm{~min}$ for $40^{\circ} \mathrm{C}$, and $0-100 \mathrm{~min}$ for $60^{\circ} \mathrm{C}$.

this work, the following three kinetic models were used to describe the behavior of the hydrolysis reaction for hydrogen generation using an integral method.

\subsubsection{Zero-order}

If the rate of consumption of $\mathrm{NaBH}_{4}\left(\mathrm{C}_{\mathrm{NaBH} 4}\right)$ with respect to time is equal to a reaction rate constant, the reaction has zeroorder kinetics (independent of any concentration).

$\frac{\mathrm{dC}_{\mathrm{NaBH}_{4}}}{\mathrm{dt}}=-r_{\mathrm{NaBH}_{4}}=-k(\mathrm{~T})$

where $C$ is the concentration, $r$ is the rate of reaction, $k$ is the reaction rate constant based on the solution volume.

Integrating the differential Eq. (6) it then becomes:

$\left(\mathrm{C}_{\mathrm{NaBH}_{4.0}}-\mathrm{C}_{\mathrm{NaBH}_{4}}\right)=k t$

A plot of $\left(\mathrm{C}_{\mathrm{NaBH}_{4,0}}-\mathrm{C}_{\mathrm{NaBH}_{4}}\right)$ should be a linear function of time, where the slope is simply the reaction rate constant. Here, the maximum hydrogen generation rate was used as an initial condition. In theory, the maximum rate occurs while the concentration of the reactants is at its highest. Since the time delay to evolve the maximum amount of hydrogen caused by the pore diffusion resistance was only about $6 \mathrm{~s}$, it is reasonable to assume that it can be applied as an initial condition. Fig. 6 shows plots of $\left(\mathrm{C}_{\mathrm{NaBH}_{4}}-\mathrm{C}_{\mathrm{NaBH}_{4}}\right)$ versus time for four temperature settings. As can be seen in Fig. 6(A), data collected before the time of $50 \mathrm{~min}$ was excluded at the temperature of $10^{\circ} \mathrm{C}$ for the linear regression due to the low reaction rate. The data at $10^{\circ} \mathrm{C}$ could be linearly regressed in the range of 50-500 min with the correlation coefficient of 0.9991 . The data at temperatures of 30,40 , and $60^{\circ} \mathrm{C}$ could be linearly regressed only within the cut-off time, where the conversion of $\mathrm{NaBH}_{4}$ is $50 \%$, as shown in Fig. 6(B-D). As can be seen from Fig. 5(A), the concentration of $\mathrm{NaBH}_{4}$ at $10^{\circ} \mathrm{C}$ is always higher than $2.5(\mathrm{~mol} / \mathrm{L})$ within the whole reaction time whereas the variations in the concentration of $\mathrm{NaBH}_{4}$ at 30,40 , and $60^{\circ} \mathrm{C}$ are greater. Therefore it is appropriate to apply the zero-order model while the concentration of $\mathrm{NaBH}_{4}$ remains high. Table 2 summarizes the following

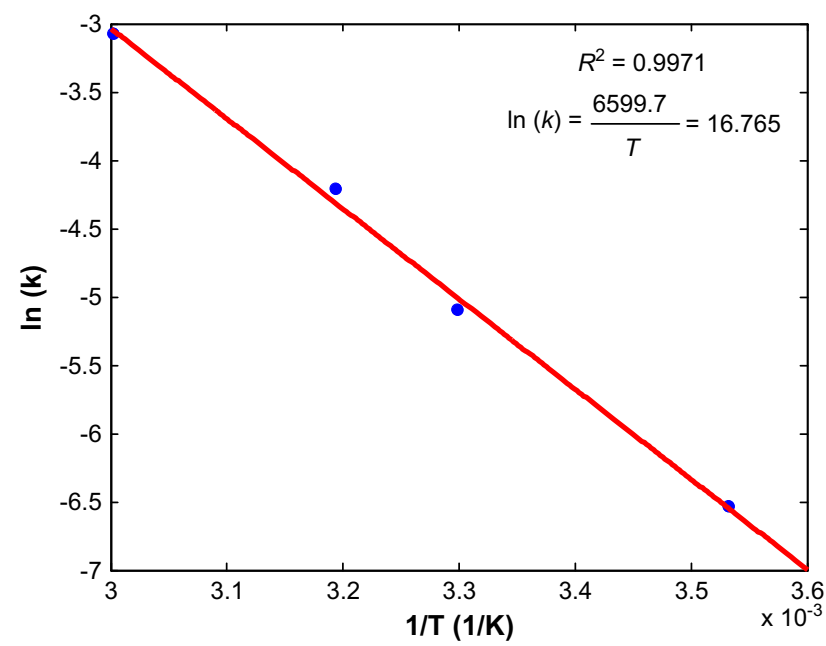

Fig. 7 - Arrhenius plot for zero-order. 
regression data for zero-order: The reaction rate constants, which are signified by the slopes of the linear regression; the correlation coefficients for regression; and the correlation coefficients for the full time span. According to the Arrhenius equation, the plot of $\ln (k)$ versus $1 / T$ for four temperature settings as shown in Fig. 7 gave a good linear regression with the correlation coefficient of 0.9971 . Therefore, the activation energy of $54.90 \mathrm{~kJ} / \mathrm{mol}$ (the slope of the linear regression) and the pre-exponential factor of $1.91 \times 10^{7} \mathrm{~mol} /$ $\mathrm{L} / \mathrm{min}$ (the intercept of the linear regression) could both be determined, as shown in Table 3 . Because of the gradual deterioration of the $\mathrm{NaBH}_{4}$ concentration at higher temperatures toward the end of the time frame, e.g., 30, 40, and $60{ }^{\circ} \mathrm{C}$, the first-order model is employed to compensate for this deterioration.

\subsubsection{First-order}

Considering the case when the reaction rate is first-order in the concentration of $\mathrm{NaBH}_{4}$, we have:

$\frac{d C_{\mathrm{NaBH}_{4}}}{\mathrm{dt}}=-r_{\mathrm{NaBH}_{4}}=-k \mathrm{C}_{\mathrm{NaBH}_{4}}$

Integrating the differential Eq. (8) it then becomes:

$\ln \left(\frac{\mathrm{C}_{\mathrm{NaBH}_{4,0}}}{\mathrm{C}_{\mathrm{NaBH}_{4}}}\right)=k t$

A plot of $\ln \left(\mathrm{C}_{\mathrm{NaBH}_{4,0}} / \mathrm{C}_{\mathrm{NaBH}_{4}}\right)$ as a function of time should give a straight line, the slope of which is the reaction rate constant. Fig. 8(A) and (B) shows that plots of $\ln \left(\mathrm{C}_{\mathrm{NaBH}_{4,0}} / \mathrm{C}_{\mathrm{NaBH}_{4}}\right)$ versus time at temperatures of 10 and $30^{\circ} \mathrm{C}$ produce good linear regression with correlation coefficients of 0.9999 and 0.9967. Nevertheless, the data at 40 and $60^{\circ} \mathrm{C}$ could be regressed linearly only over the full cut-off time. The reason for this is that higher temperatures bring about higher reaction rates, thus this significantly increases the effect of the adsorption of $\mathrm{NaBH}_{4}$ on the catalyst. Table 2 summarizes the following regression data for a first-order model: the reaction rate constants, the correlation coefficients from the linear regression and the correlation coefficients for the entire range. The Arrhenius plot, which is $\ln (k)$ versus $1 / T$, for first-order is shown in Fig. 9. The activation energy and the pre-exponential factor can then be obtained from the slope and intercept of the regression line, being $55.70 \mathrm{~kJ} / \mathrm{mol}$ and $9.53 \times 10^{6} 1 / \mathrm{min}$ as shown in Table 3 . The regression results indicate that neither zero-order nor first-order can describe the hydrogen generation rate over the entire experimental duration at higher temperatures (40 and $60^{\circ} \mathrm{C}$ ). The Langmuir-Hinshelwood model is considered next.

\subsubsection{Langmuir-Hinshelwood}

The Langmuir-Hinshelwood model [7,23] is commonly used to describe reaction kinetics for catalytic reactions. Consider the following rate expression:

$\frac{d C_{\mathrm{NaBH}_{4}}}{\mathrm{dt}}=-r_{\mathrm{NaBH}_{4}}=-k \frac{\mathrm{K}_{\mathrm{a}} \mathrm{C}_{\mathrm{NaBH}_{4}}}{1+\mathrm{K}_{\mathrm{a}} \mathrm{C}_{\mathrm{NaBH}_{4}}}$

where $K_{\mathrm{a}}$ is the adsorption constant which is assumed to be a constant. Integrating Eq. (10), one obtains:

$\frac{1}{K_{a}} \ln \left(\frac{C_{\mathrm{NaBH}_{4,0}}}{C_{\mathrm{NaBH}_{4}}}\right)+\left(C_{\mathrm{NaBH}_{4,0}}-\mathrm{C}_{\mathrm{NaBH}_{4}}\right)=k t$
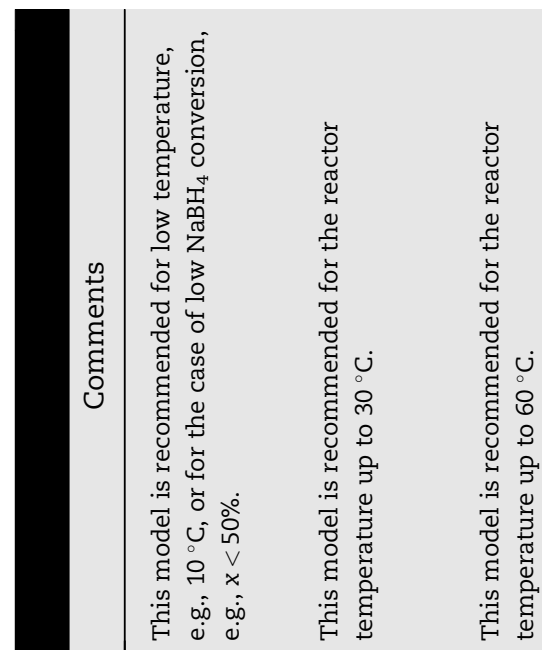

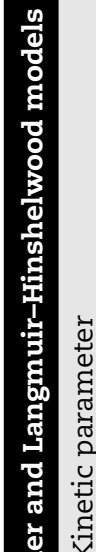

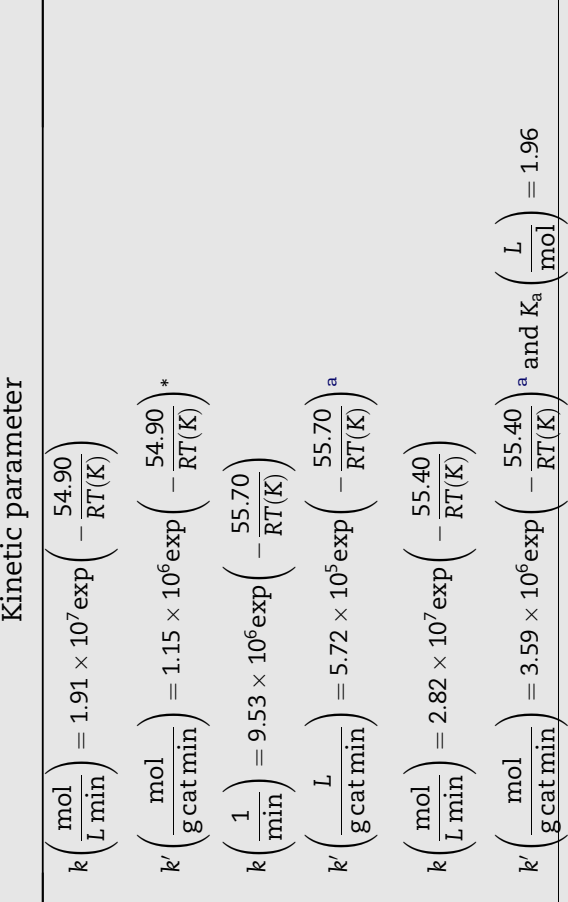

急

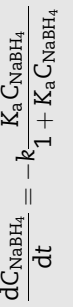




\section{A $10^{\circ} \mathrm{C}$}

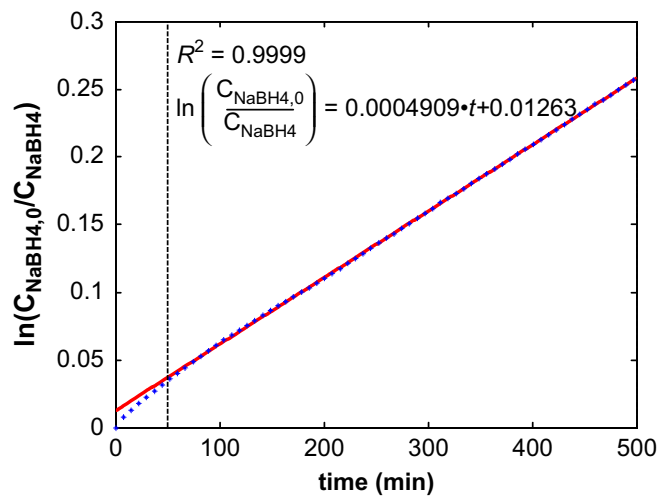

C $\quad 40^{\circ} \mathrm{C}$

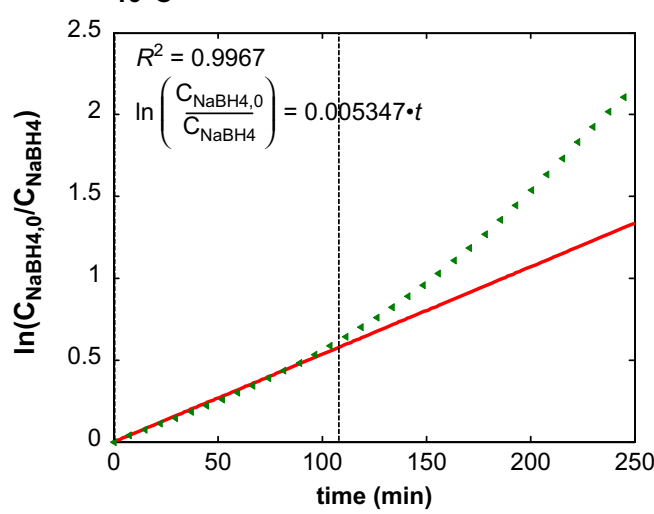

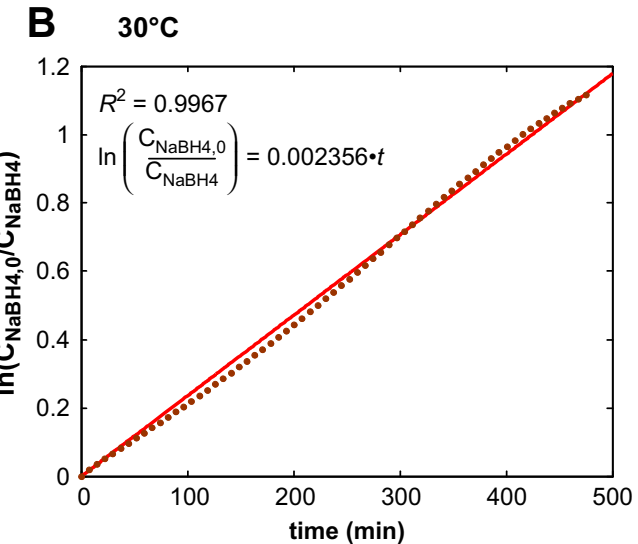

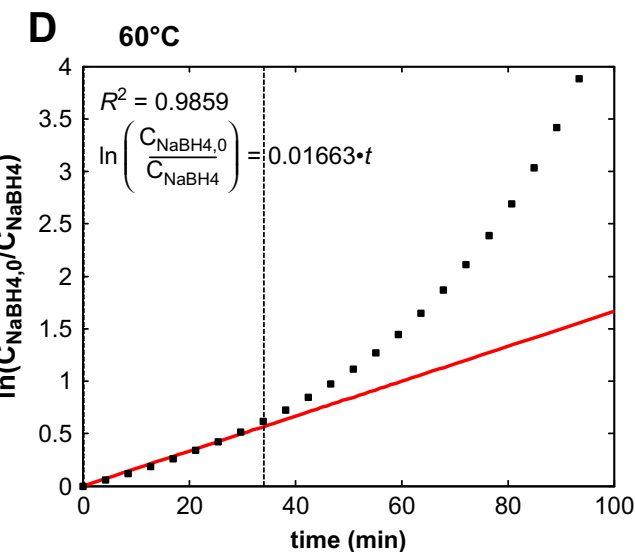

Fig. 8 - Linear regression based on first-order while the temperature is (A) $10^{\circ} \mathrm{C}$ (B) $30^{\circ} \mathrm{C}$ (C) $40^{\circ} \mathrm{C}$ (D) $60^{\circ} \mathrm{C}$.

A plot of $\left(1 / \mathrm{K}_{\mathrm{a}}\right) \ln \left(\mathrm{C}_{\mathrm{NaBH}_{4,0}} / \mathrm{C}_{\mathrm{NaBH}_{4}}\right)+\left(\mathrm{C}_{\mathrm{NaBH}_{4,0}}-\mathrm{C}_{\mathrm{NaBH}_{4}}\right)$ as a function of time should give a straight line, the slope of which is the reaction rate constant. The objective function can be minimized by varying the adsorption constant using the data at 40 and $60^{\circ} \mathrm{C}$. Therefore, it can be formulated as follows:

$\min _{K_{a}} f\left(K_{a}\right)=\left(1-R_{40{ }^{\circ} \mathrm{C}}^{2}\right)+\left(1-R_{60}^{2}{ }^{\circ} \mathrm{C}\right)$

where $R^{2}$ is the correlation coefficient. Fig. 10 shows that the optimal adsorption constant $\left(K_{\mathrm{a}, \mathrm{opt}}\right)$ was obtained by

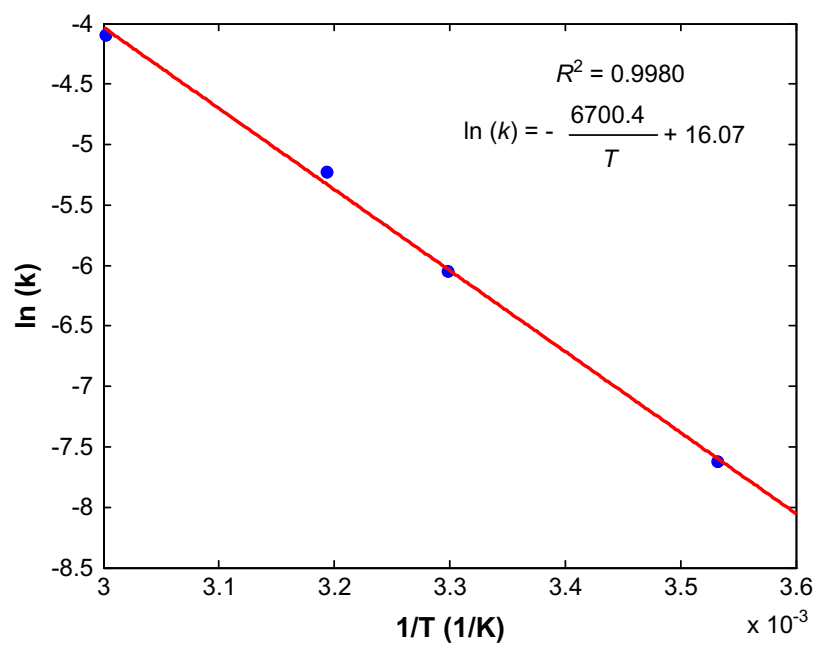

Fig. 9 - Arrhenius plot for first-order. minimizing Eq. (12) at temperatures of 40 and $60{ }^{\circ} \mathrm{C}$. In order to determine the reaction rate constant for Langmuir-Hinshelwood, the optimal adsorption constant was input into the data at temperatures of 10 and $30^{\circ} \mathrm{C}$, as shown in Fig. 11(A) and (B). As can be seen in Fig. $11(\mathrm{C})$ and (D), the data at 40 and $60^{\circ} \mathrm{C}$ could be linearly regressed within the whole time span. Table 2 also shows the reaction rate constants, the correlation

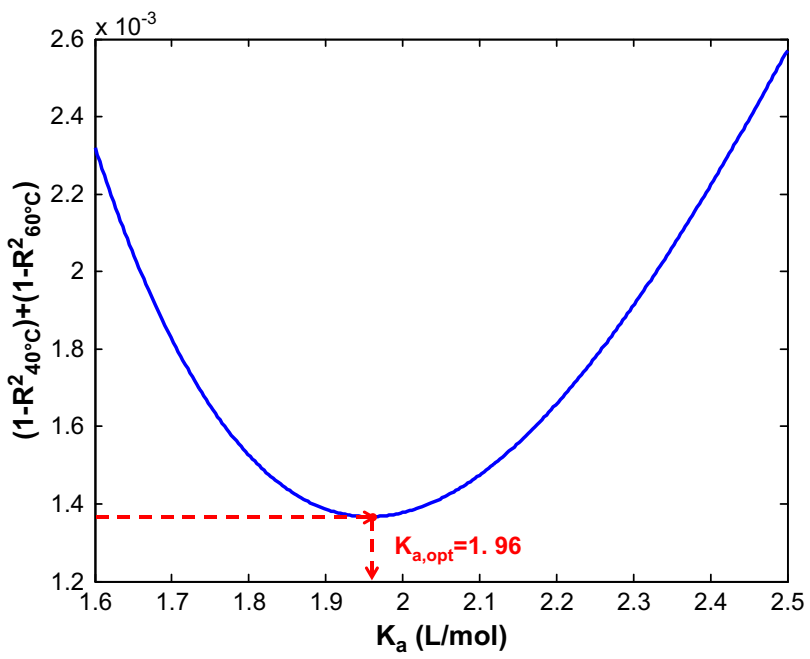

Fig. 10 - Optimization of the adsorption constant for Langmuir-Hinshelwood using the data at 40 and $60^{\circ} \mathrm{C}$. 

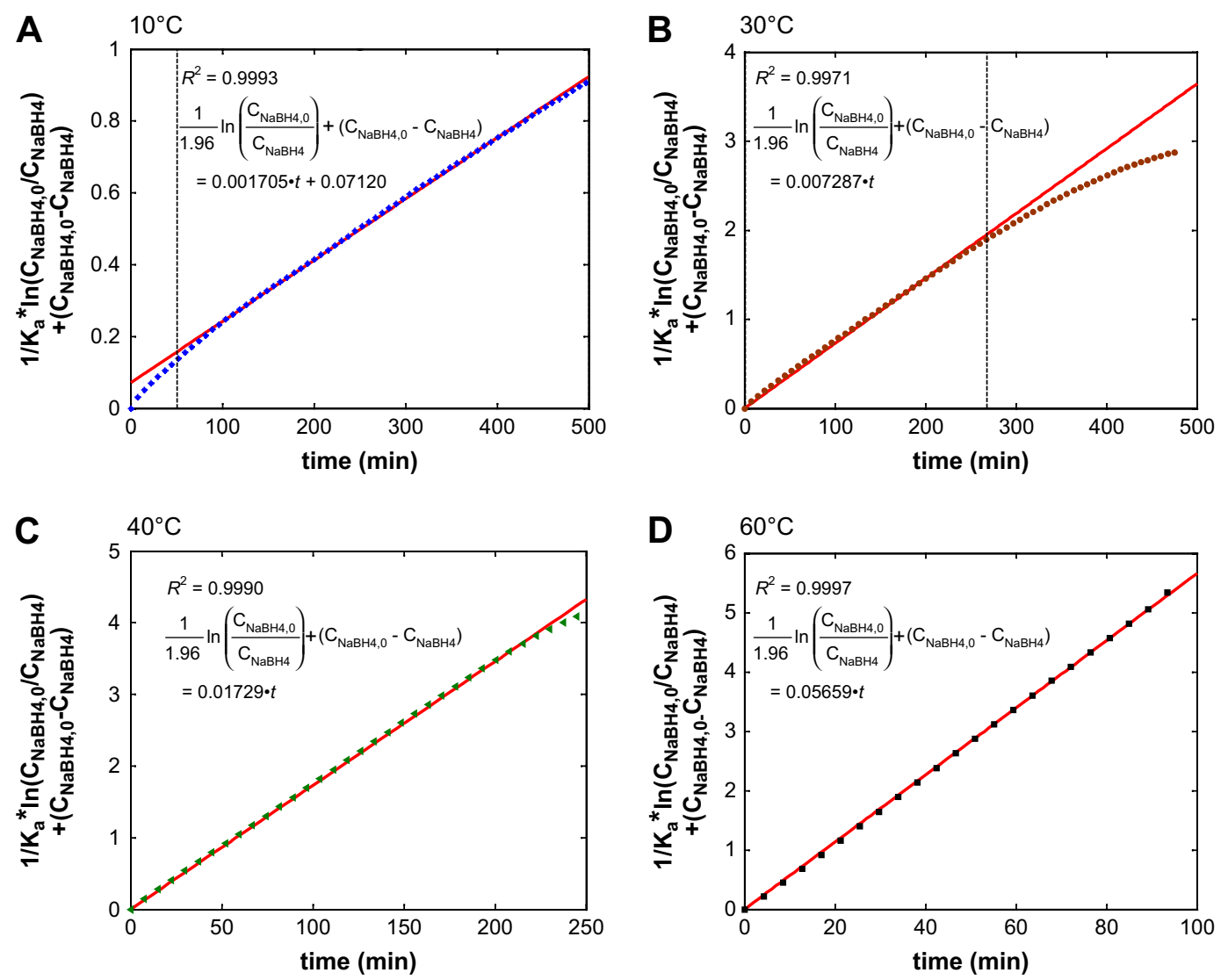

Fig. 11 - Linear regression based on Langmuir-Hinshelwood with the temperature set at (A) $10^{\circ} \mathrm{C}(\mathrm{B}) 30^{\circ} \mathrm{C}(\mathrm{C}) 40^{\circ} \mathrm{C}(\mathrm{D}) 60^{\circ} \mathrm{C}$.

coefficients of both regression and the entire range for Langmuir-Hinshelwood. Therefore from the Arrhenius plot of $\ln (k)$ versus $1 / \mathrm{T}$ as shown in Fig. 12, the activation energy and the pre-exponential factor could be determined to be $55.40 \mathrm{~kJ} / \mathrm{mol}$ and $2.82 \times 10^{7} \mathrm{~mol} / \mathrm{L} / \mathrm{min}$. The reaction rate constants based on the solution volume and the catalyst weight for zero-order, first-order, and Langmuir-Hinshelwood are summarized in Table 3.

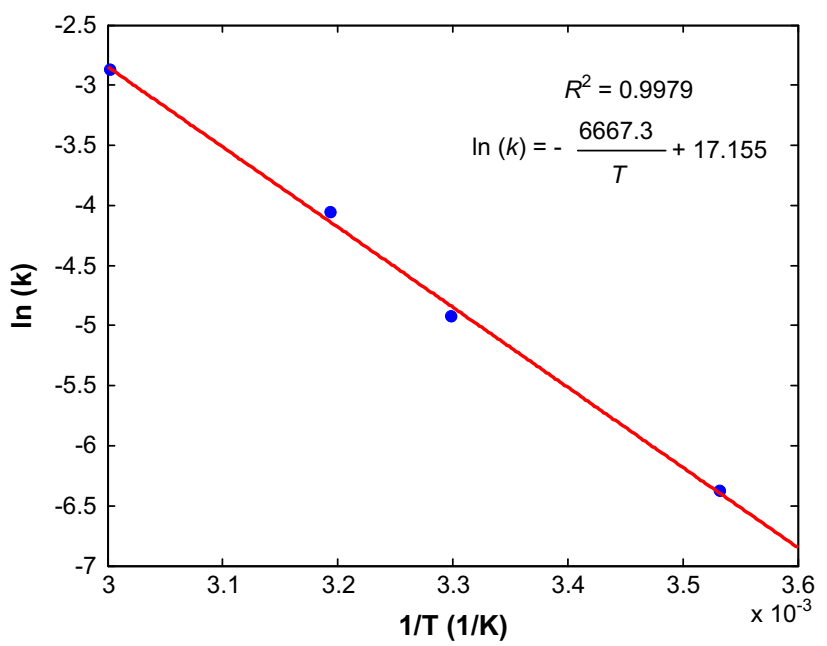

Fig. 12 - Arrhenius plot for Langmuir-Hinshelwood.

\subsection{Batch reactor model}

With the kinetic models available, a constant-pressure batch reactor model can be constructed. From the mole balance and

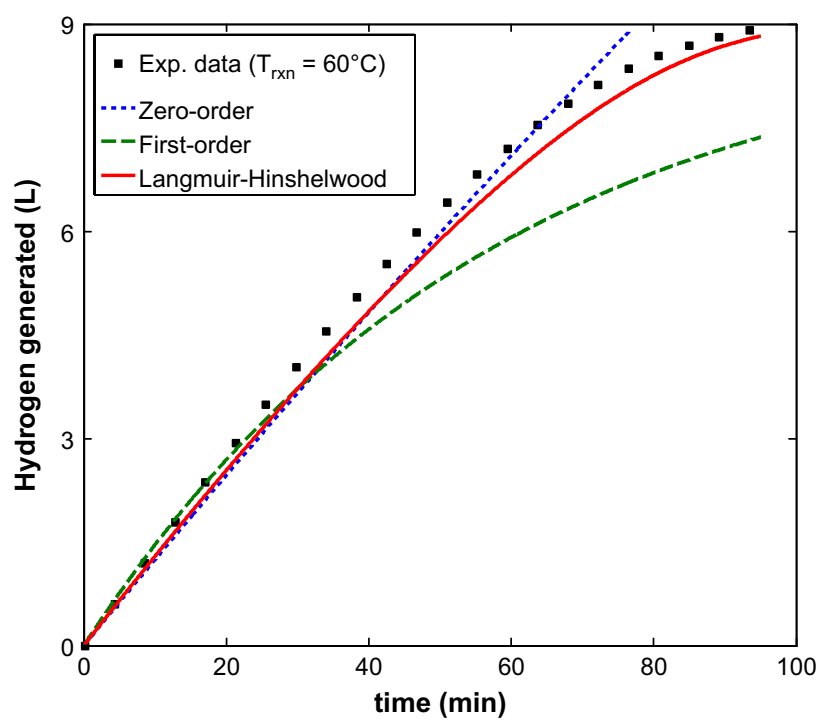

Fig. 13 - Model predictions for zero-order, first-order, and Langmuir-Hinshelwood with the experimental data at $60^{\circ} \mathrm{C}$. 
the stoichiometric relationship the variation of the number of moles of $\mathrm{NaBH}_{4}$ with respect to time is the product of the rate of reaction and the solution volume, which can be expressed as follows:

$\frac{\mathrm{d}\left(\mathrm{VC}_{\mathrm{NaBH}_{4}}\right)}{\mathrm{dt}}=\left(-r_{\mathrm{NaBH}_{4}}\right) \mathrm{V}$

The variation of the number of moles of $\mathrm{H}_{2} \mathrm{O}$ with respect to time is:

$\frac{\mathrm{d}\left(\mathrm{VC}_{\mathrm{H}_{2} \mathrm{O}}\right)}{\mathrm{dt}}=2\left(-\mathrm{r}_{\mathrm{NaBH}_{4}}\right) \mathrm{V}$

The variation of the number of moles of $\mathrm{NaBO}_{2}$ with respect to time is:

$\frac{\mathrm{d}\left(\mathrm{VC}_{\mathrm{NaBO}_{2}}\right)}{\mathrm{dt}}=r_{\mathrm{NaBH}_{4}} \mathrm{~V}$

The solution volume can be calculated in Eq. (5) and the concentration profiles of $\mathrm{NaBH}_{4}, \mathrm{H}_{2} \mathrm{O}$, and $\mathrm{NaBO}_{2}$ can then be obtained. The hydrogen generation rate can be computed as follows:

$F_{\mathrm{H}_{2}}=4\left(r_{\mathrm{NaBH}_{4}} V\right) \frac{M_{\mathrm{H}_{2}}}{\rho_{\mathrm{H}_{2}}}$

where $F_{\mathrm{H}_{2}}$ is the hydrogen generation rate. Because of the constant reaction temperature, the energy balance equations are negligible in this system. Eqs. (13)-(15) can be solved by using the Euler method, the code is programmed in FORTRAN.

\subsection{Validation of the kinetic model}

The hydrogen generated from the hydrolysis reaction of an alkaline $\mathrm{NaBH}_{4}$ solution can be used for PEM fuel cell applications due to its high purity. The operating fuel cell temperature is normally set at $60^{\circ} \mathrm{C}$ for optimal performance. For this reason, the experimental data at $60^{\circ} \mathrm{C}$ was used to validate the kinetic models, which are zero-order, first-order, and Langmuir-Hinshelwood. As can be seen in Fig. 13, the Langmuir-Hineshelwood model gave the best prediction among the three models.

\section{Conclusions}

In this study, the catalyst $\mathrm{Ru} / \gamma-\mathrm{Al}_{2} \mathrm{O}_{3}$ was prepared by the impregnation-reduction method for the hydrogen generation from the hydrolysis reaction of an alkaline $\mathrm{NaBH}_{4}$ solution. Next, the reaction was carried out in a batch reactor at 10,30 , 40 and $60{ }^{\circ} \mathrm{C}$, respectively, until at least $70 \%$ conversion was achieved, except for the case of $10^{\circ} \mathrm{C}$ when the reaction was terminated at $500 \mathrm{~min}$. The results indicate that the zeroorder model can only be applied for low conversion, e.g., $x<50 \%$, and/or low temperature, e.g., $10^{\circ} \mathrm{C}$. The first-order model shows somewhat better applicability and gives a reasonably good concentration trajectory for temperatures up to $30^{\circ} \mathrm{C}$. The Langmuir-Hinshelwood model gives reasonable behavior description for the entire temperature range of interest, $10-60^{\circ} \mathrm{C}$. Therefore, the Langmuir-Hinshelwood model is recommended for the hydrogen generation device modeling and design.

\section{Acknowledgement}

This work is supported in part by the National Science Council of Taiwan.

\section{Appendix}

The raw data is filtered by an exponential filter with a time constant of $0.42 \mathrm{~min}$, i.e., $\mathrm{F}_{\mathrm{H}_{2}}=\mathrm{F}_{\mathrm{H}_{2}} /(0.42 \mathrm{~s}+1)$. Fig. A1 shows the hydrogen generation rate before (in blue) and after (in red) filtering at $30^{\circ} \mathrm{C}$ (Fig. A1(A)) and $60^{\circ} \mathrm{C}$ (Fig. A1(B)). (For interpretation of the references to color in this figure, the reader is referred to the web version of this article.)

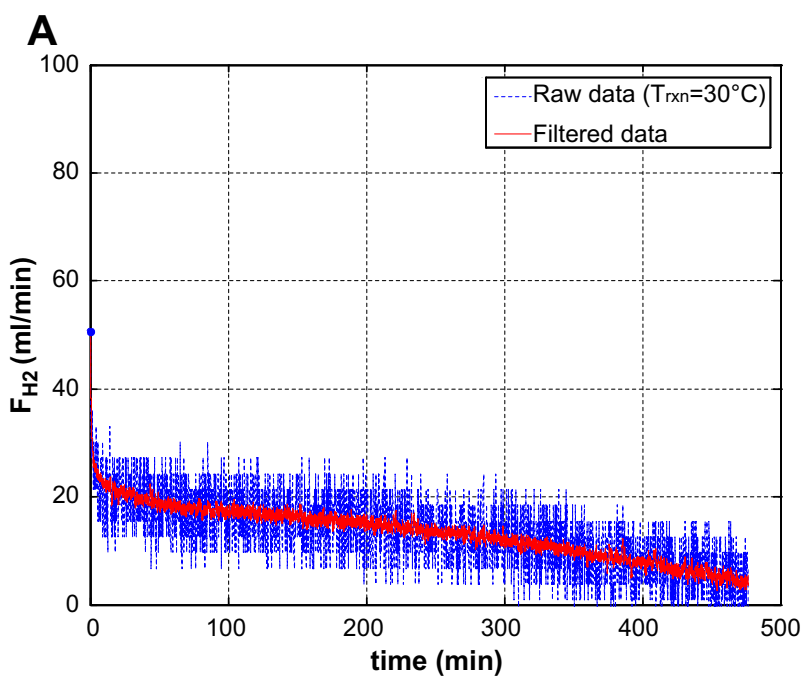

B

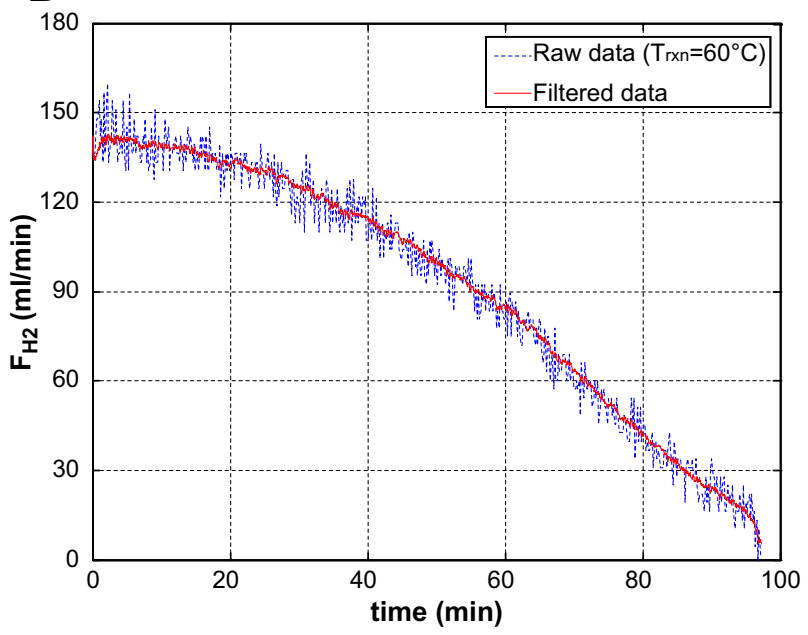

Fig. A1 - Raw data and filtered data at (A) $30^{\circ} \mathrm{C}$ and (B) $60^{\circ} \mathrm{C}$.

\section{R E F E R E N C E S}

[1] Amendola SC, Sharp-Goldman SL, Janjua MS, Kelly MT, Petillo PJ, Binder M. An ultrasafe hydrogen generator: aqueous, alkaline borohydride solutions and Ru catalyst. J Power Sources 2000;85(2):186-9. 
[2] Amendola SC, Sharp-Goldman SL, Janjua MS, Spencer NC, Kelly MT, Petillo PJ, et al. A safe, portable, hydrogen gas generator using aqueous borohydride solution and $\mathrm{Ru}$ catalyst. Int J Hydrogen Energy 2000;25(10):969-75.

[3] Hsueh CL, Chen CY, Ku JR, Tsai SF, Hsu YY, Tsau F, et al. Simple and fast fabrication of polymer template-Ru composite as a catalyst for hydrogen generation from alkaline $\mathrm{NaBH}_{4}$ solution. J Power Sources 2008;177(2):485-92.

[4] Ozkar S, Zahmakiran M. Hydrogen generation from hydrolysis of sodium borohydride using $\mathrm{Ru}(0)$ nanoclusters as catalyst. J Alloys Compd 2005;404:728-31.

[5] Zahmakiran M, Ozkar S. Water dispersible acetate stabilized ruthenium(0) nanoclusters as catalyst for hydrogen generation from the hydrolysis of sodium borohyride. J Mol Catal A Chem 2006;258(1-2):95-103.

[6] Shang YH, Chen R. Semiempirical hydrogen generation model using concentrated sodium borohydride solution. Energy Fuels 2006;20(5):2149-54.

[7] Zhang JS, Delgass WN, Fisher TS, Gore JP. Kinetics of Rucatalyzed sodium borohydride hydrolysis. J Power Sources 2007;164(2):772-81.

[8] Kojima Y, Suzuki K, Fukumoto K, Sasaki M, Yamamoto T, Kawai $Y$, et al. Hydrogen generation using sodium borohydride solution and metal catalyst coated on metal oxide. Int J Hydrogen Energy 2002;27(10):1029-34.

[9] Kojima Y, Suzuki K, Fukumoto K, Kawai Y, Kimbara M, Nakanishi H, et al. Development of $10 \mathrm{~kW}$-scale hydrogen generator using chemical hydride. J Power Sources 2004; 125(1):22-6.

[10] Patel N, Patton B, Zanchetta C, Fernandes R, Guella G, Kale A, et al. Pd-C powder and thin film catalysts for hydrogen production by hydrolysis of sodium borohydride. Int J Hydrogen Energy 2008;33(1):287-92.

[11] Liu BH, Li ZP, Suda S. Nickel- and cobalt-based catalysts for hydrogen generation by hydrolysis of borohydride. J Alloys Compd 2006;415(1-2):288-93.

[12] Metin O, Ozkar S. Hydrogen generation from the hydrolysis of sodium borohydride by using water dispersible, hydrogenphosphate-stabilized nickel(0) nanoclusters as catalyst. Int J Hydrogen Energy 2007;32(12):1707-15.

[13] Ye W, Zhang HM, Xu DY, Ma L, Yi BL. Hydrogen generation utilizing alkaline sodium borohydride solution and supported cobalt catalyst. J Power Sources 2007;164(2): 544-8.

[14] Malvadkar N, Park S, Urquidi-MacDonald M, Wang H, Demirel MC. Catalytic activity of cobalt deposited on nanostructured poly( $p$-xylene) films. J Power Sources 2008; 182(1):323-8.

[15] Jeong SU, Kim RK, Cho EA, Kim HJ, Nam SW, Oh IH, et al. A study on hydrogen generation from $\mathrm{NaBH}_{4}$ solution using the high-performance Co-B catalyst. J Power Sources 2005;144(1): 129-34.

[16] Zhao JZ, Ma H, Chen J. Improved hydrogen generation from alkaline $\mathrm{NaBH}_{4}$ solution using carbon-supported Co-B as catalysts. Int J Hydrogen Energy 2007;32(18):4711-6.

[17] Dong H, Yang HX, Ai XP, Cha CS. Hydrogen production from catalytic hydrolysis of sodium borohydride solution using nickel boride catalyst. Int J Hydrogen Energy 2003;28(10): 1095-100.

[18] Ingersoll JC, Mani N, Thenmozhiyal JC, Muthaiah A. Catalytic hydrolysis of sodium borohydride by a novel nickel-cobaltboride catalyst. J Power Sources 2007;173:450-7.

[19] Pena-Alonso R, Sicurelli A, Callone E, Carturan G, Raj R. A picoscale catalyst for hydrogen generation from $\mathrm{NaBH}_{4}$ for fuel cells. J Power Sources 2007;165(1):315-23.

[20] Zhang JS, Fisher TS, Gore JP, Hazra D, Ramachandran PV. Heat of reaction measurements of sodium borohydride alcoholysis and hydrolysis. Int J Hydrogen Energy 2006; 31(15):2292-8.

[21] Brown HC, Brown CA. New, highly active metal catalysts for the hydrolysis of borohydride. J Am Chem Soc 1962;84: 1493-4.

[22] Gervasio D, Tasic S, Zenhausern F. Room temperature microhydrogen-generator. J Power Sources 2005;149:15-21.

[23] Fogler HS. Elements of chemical reaction engineering. New Jersey: Prentice-Hall; 1999. 